\title{
Starting With the Space: Integrating Learning Spaces and Technologies
}

\author{
Gina Sanchez Gibau \\ IUPUI \\ gsanchez@iupui.edu \\ Francia Kissel \\ IUPUI \\ fkissel@iupui.edu \\ Modupe Labode \\ National Museum of American History \\ modupe.labode@gmail.com
}

\begin{abstract}
Teaching introductory courses to college freshmen requires innovative pedagogies, which are often powered by new advanced technologies that potentially increase student engagement. In addition, instructors may also plan and deploy active-learning strategies that first consider the physical spaces in which learning will take place. Effective pedagogies acknowledge both the impact that space has on student learning and the ability of both "low" and "bigh" technologies to facilitate such learning, merging the inherent power of each. The following case study provides an example of a themed learning community as a vehicle through which instructors may maximize technologies and spaces to enhance the teaching and learning process. The case study bighlights the use of both physical learning spaces (e.g., cutting-edge active-learning classrooms; traditional classrooms; the off-campus settings of museums) and learning technologies (e.g., high-technology tools such as image-sharing software vs. lowtechnology white boards and paper-based pop-up museum exbibits) to illustrate the ways in which instructional teams collaborate to intentionally design meaningful learning experiences for their students.

Keywords: active-learning classroom, high-impact practices, pedagogy, synthesis, reflection, instructional strategies, transparent assignments, collaborative learning
\end{abstract}

Instructors who are attentive to the current realities of 21 st-century higher education recognize that learning occurs both within and outside the classroom, in spaces where technologies may range from cutting edge to seemingly absent. Therefore, effective pedagogies acknowledge both the impact that space has on student learning and the utility of both "low" and "high" technologies to facilitate such learning, merging the inherent power of each. Starting with the space is key to the design of learning experiences for undergraduate students. What features of each learning space can be utilized to fulfill the specific learning objectives? What technologies can be harnessed to engage students, focus their attention, and help them achieve the learning objectives? This case study serves as an example of an integrative, student-centered instructional strategy designed to facilitate the first-year student learning experience while challenging the conventional notions of space, technology, and pedagogy and the uses of each. 


\section{Literature Review}

\section{Learning Communities}

A majority of U.S. tertiary institutions pay special attention to beginning students through first-year programs, most commonly through offering first-year seminars or learning communities (Field, 2018; Zhao \& Kuh, 2004). Learning communities are two or more linked courses that focus on a common theme or topic. Considered a high-impact practice in themselves, learning communities often incorporate other high-impact interventions, including service learning, common intellectual experiences (such as a common reader), community engagement, and other practices (Stebleton, Jensen, \& Peter, 2010). The members of the community include the cohort of students who enroll concurrently in the courses, the professors who teach the linked courses, and often, librarians or student affairs personnel.

The rationale for offering these curricular links is that they support first-year students, facilitating gains in retention as students become engaged in their learning and thus committed to the college experience (Lardner \& Malnarich, 2008; Zepke, 2013). In addition to the retention gains desired by institutions, other aims target student learning outcomes, as Kuh (2008) explained: "The key goals for learning communities are to encourage integration of learning across courses and to involve students with 'big questions' that matter beyond the classroom" (p. 10). However, not all learning communities fulfill such aspirational goals; often, they "can be a set of disconnected experiences, described in an arcane and unfamiliar language, which appear to have no relevance to [students'] lives” (Mills \& Mehaffy, 2016, p. 58).

\section{Active Learning Strategies and Integrated Learning}

The best-planned learning communities select strategies that correlate with success but also provide a framework for integrative learning. The 2007 summary report to the National Postsecondary Education Cooperative's initiative on student success listed a set of strategies positively correlated in the literature with student success:

high expectations that students will succeed, curricular and behavioral integration, pedagogies involving active learning and collaboration, frequent feedback, time on task, respect and engagement with diversity, frequent contact with faculty, connections between academic and non-academic experiences, and an emphasis on the first year of study. (Ewell \& Wellman, 2007, p. 5)

Furthermore, using multiple high-impact practices has been shown to have "cumulative, additive effects" (Kuh, 2016).

Particularly prevalent in learning communities is the use of active and collaborative learning activities and often, learning outside the classroom, according to the National Survey of Student Engagement (Zhao \& Kuh, 2004). Active learning has been defined as "anything course-related that all students in a class session are called upon to do other than simply watching a lecture and taking notes" (Felder \& Brent, 2009, p. 2). Faculty may find it challenging to incorporate active-learning strategies in their own classrooms (Stebleton et al., 2010), but more challenging is the task of incorporating outcomes that complement the curricula offered by the individual instructors in a cohesive way. An even greater level of difficulty arises when the instructional team plans a singular, integrative assignment, which is assigned in each of the courses and evaluated by each instructor in the learning community. Yet, such assignments can give a focus to the entire enterprise; in fact, some 
learning community experts consider an integrative assignment to be as fundamental as the use of active and collaborative pedagogies (Lardner \& Malnarich, 2008).

\section{Active Learning and Instructional Environments}

When choosing from active-learning pedagogies, one of the first considerations must be instructional space because the affordances available within a space shape the specific strategies that can be used. The term affordances refers to the characteristics of spaces and objects that determine how those features should be used (Rands \& Gansemer-Topf, 2017). For example, the SCALE-UP Project of the Physics Department of North Carolina State University showed that a classroom with round tables is more conducive to both small-group discussion and intergroup sharing than a classroom with fixed seating (Beichner et al., 2007).

Universities are paying increasing attention to the physical spaces of not only classrooms (Rands \& Gansemer-Topf, 2017) but also student gathering areas (Morieson, Murray, Wilson, Clarke, \& Lukas, 2018), study spaces (Bennett, 2007), and even corridors. Structural changes to these spaces have been driven by theories of cognition, pedagogical responses to those theories, and changes in the characteristics of learners themselves (Oblinger, 2006). Today's students differ from prior generations in that they prefer hands-on learning, rely on media for both social and academic uses, and have more time constraints (Oblinger, 2006). In addition, they are "prosumers," both creating and consuming media content equally (Valenti, 2015, p. 34).

To fit the new paradigm in learning, newly designed classrooms (often termed ALCs-activelearning classrooms) are carefully created to enhance student engagement (Rands \& Gansemer-Topf, 2017). Fundamentally, all classrooms reflect what Torin Monahan called "built pedagogy," meaning that the designers' underlying assumptions about education are embodied in the spaces meant for student learning, and characteristics of those structures can proscribe or encourage certain behaviors (2005, pp. 34-35). So, when active behaviors are desired, characteristics that inform the design of ALCs might include density, or ratio of students per space (Graetz, 2006; Herzog, 2007); seating, including the type (Brooks, 2011) and the proximity to the instructor (Herzog, 2007); and technology-rich features (Brooks, 2011). An ideal ALC should have "furniture and technology settings that foster small-group collaboration, a rich-media working environment, and the ability to easily reconfigure within the class period" (Valenti, 2015, p. 36). Other considerations might include easily available lab equipment and means for students to report and display results (Beichner et al., 2007).

Such redesigns of learning spaces spark professional development efforts; for example, the Transform, Interact, Learn, Engage (TILE) program at University of Iowa and the Mosaic Initiative at Indiana University offer workshops, consultations, peer sharing, classroom tours, and research opportunities to faculty (Morrone et al, 2017). As instructors redesign courses and lesson plans to fit new spaces, they engage in critical reflection that enriches their teaching practice in both traditional and new spaces (Gierdowski, 2017, pp. 170-171) and they come to see themselves as learners (Phillipson, Riel, \& Leger, 2018). Mills and Mehaffy (2018, p. 59) concluded, "But in fact our job is not to teach. Our job is to create the environment that optimizes learning for our students."

\section{Instructional Environments Outside the Classroom}

Another way of optimizing learning for students is to take learning out of the classroom. Although college students are enthusiastic at the words "field trip," most have little idea of the deep learning they will encounter as they use course concepts in real situations. Examples of learning outside of the classroom include service learning, community engagement, internships, fieldwork, outdoor education, and study abroad (Bandy, 2018). Faculty may also capitalize on existing programs or events 
offered through student affairs for on-campus but out-of-class experiences (James \& Hudspeth, 2017; Lardner \& Malnarich, 2008).

In addition to making abstract concepts concrete through participatory experiences, experiential learning has a number of other benefits, depending on design. Students can gain autonomy in solving problems (Perrin, 2014); the capacity to think critically and to apply knowledge to illstructured problems (Eyler, 2009); the ability to give valuable feedback to peers and to learn from their own feedback (Perrin, 2014); lifelong learning and work-related skills including "soft skills" desired by employers (Bandy, 2018; Eyler, 2009). An off-campus field trip in the first year of college cannot impart all of the above benefits, but it serves as a jumping-off place to get students excited and engaged in their education. Additionally, a field trip can serve as the basis for an integrated assignment in a learning community (see Stebleton et al., 2010, for an example). The key, though, is to make the experience and resultant assignment meaningful, as research shows that students will "persist in their studies if the learning they experience is meaningful, deeply engaging, and relevant to their lives" (Lardner \& Malnarich, 2008, p. 32).

\section{Themed Learning Communities}

\section{"The Human Story" Themed Learning Community}

The setting of this case study is IUPUI, a large urban public research campus of Indiana University (IU) situated within the city's downtown area. Historically at IUPUI, the learning community model has been implemented through "themes" that link a series of general education courses. The case analyzed here is a themed learning community or "TLC" offered during the fall 2018 semester comprising three courses (Introduction to Cultural Anthropology, Understanding Museums, and First Year Success Seminar) and organized around the theme of "The Human Story." The development of this theme focused on two primary questions: How does culture shape people and their unique identities? And how are the stories of individuals and communities preserved and relayed to others through museums in ways that connect to contemporary social issues? These questions then led the three instructors to craft the following learning outcome for the TLC: "Students will demonstrate how the human stories preserved and relayed through museums connect to their own lives and to contemporary social issues." We developed this learning outcome with the recognition, similar to Abma's (2000; as cited in Araujo et al., 2014, p. 23), that human stories are powerful and as such can serve as "tools in learning, because they are the most fundamental ways to order experiences and events." This learning outcome then shaped our development of deliberate integrative activities that were enhanced within and across each classroom space.

The goal and intent of this theme was to enable learners to explore their own stories, as well as to study the ways the stories of others are represented, specifically through the disciplines of cultural anthropology and museum studies. ${ }^{1}$ A unique feature of the TLC initiative is the integration of cocurricular activities to enhance the learning process and to facilitate first-year student adjustment and socialization. Such activities require students and their instructors to engage in meaningful, collective activities beyond the classroom. For this TLC, we and our 25 students visited five local museums: the Indianapolis Museum of Art; the Indiana Medical History Museum; the Indiana State Museum; the

\footnotetext{
${ }^{1}$ The close, often contentious, historical relationship between anthropology and museums was a theme of the Understanding Museums course, particularly in connection to issues such as interpretation of indigenous people, unauthorized display of human remains or objects of cultural significance in museums, and the role museums can play in forming and creating community.
} 
Indianapolis Zoo; and the Eiteljorg Museum of American Indians and Western Art. ${ }^{2}$ The exhibitions, programs, and presentations at each selected museum provided visitors with information related to various aspects of human culture, to ensure connection with anthropological concepts. ${ }^{3}$ In addition, each museum visit helped students understand more about the city and community in which they were studying, as well as to develop their critical thinking skills, their sense of aesthetics, and their ability to integrate disciplinary knowledge.

A key feature of the TLC model is the collaboration that occurs among co-instructors, who work as a team to incorporate the learning objectives for students across the classes. Teamwork is facilitated through regular meetings and visits to each other's classes. We have been involved in TLCs, both separately and together, for a number of years and thus have a wealth of knowledge and experience to bring to bear as we engaged in purposeful course design for this particular TLC. As we discussed the learning activities for our individual courses and for the shared activities, space became an integral component of the planning process.

\section{Space Matters}

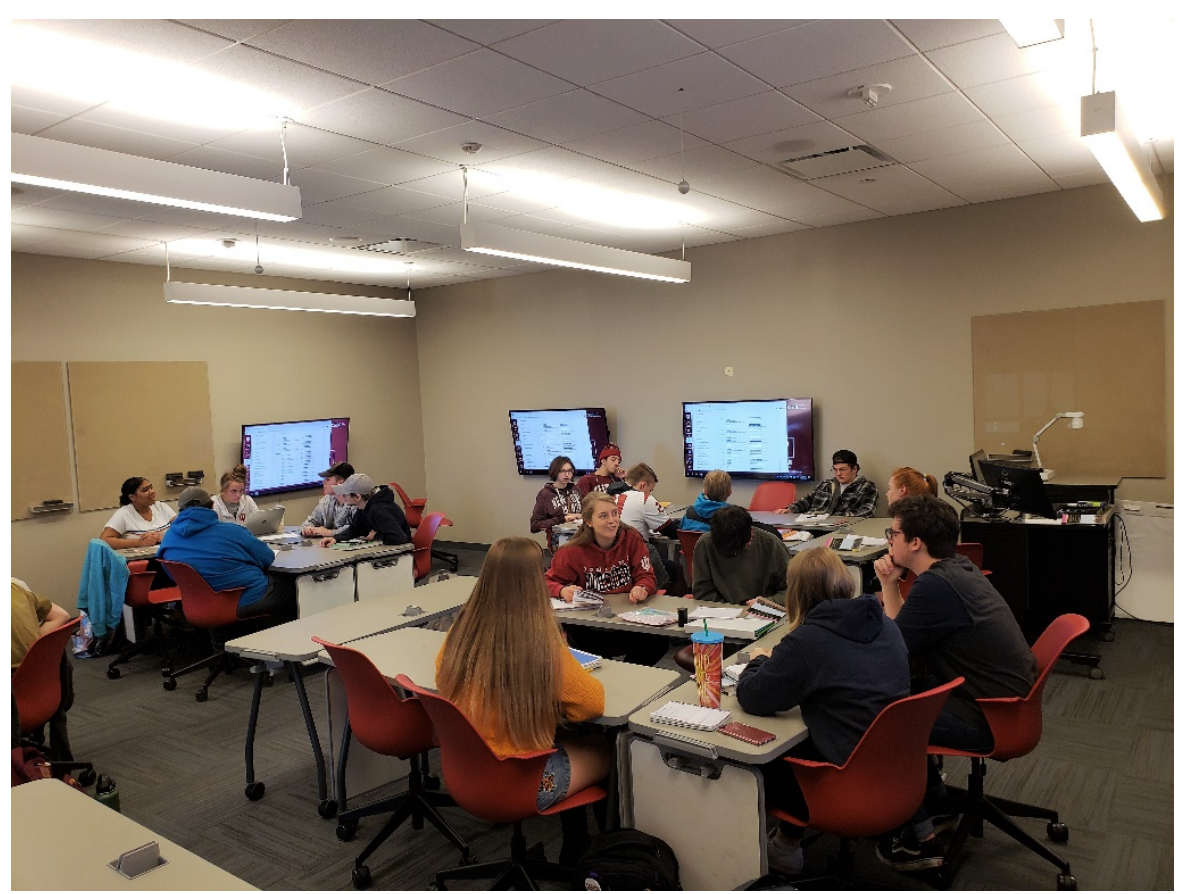

Figure 1. An active-learning "Mosaic" classroom at IUPUI, November, 2018. Photo courtesy G. Gibau.

Three types of spaces were considered in designing the pedagogy for this TLC: classroom space, with its attendant technologies; out-of-class learning spaces, such as the library and museums;

\footnotetext{
${ }^{2}$ We included the zoo as a museum for two reasons. First, museum professional organizations consider zoos to be museums (American Alliance of Museums, 2019). Second, the Indianapolis Zoo's mission to “empower people and communities, both locally and globally, to advance animal conservation" is aligned with the TLC's theme of the human story.

${ }^{3}$ The students did not pay entrance fees to the museums. The Indianapolis Museum of Art and the Eiteljorg provided free admission to IUPUI students; the faculty received free admission to the IMA because they were accompanying a class trip. A subsidy for programming provided by IUPUI's first-year experience program covered the reduced admission costs to the remaining museums. There was no transportation provided, so students either walked or carpooled to the museums.
} 
and a campus meeting room for the pop-up museum exhibits and final presentations. The space of a classroom can influence how a class will be taught. Two of the three courses took place in "Mosaic" classrooms, while the third classroom, which was the laboratory for IUPUI's Museum Studies Program, had flexible seating that could be arranged for student collaboration. The IU Mosaic Initiative is one of many at the national level attempting to transform traditional classroom spaces into new configurations that facilitate active-learning strategies (Beichner et al., 2007; Harvey \& Kenyon, 2013; Rands \& Gansemer-Topf, 2017). Key to the transformation is embedding advanced and collaborative technologies, whiteboard surfaces, and movable furniture. The idea behind the Mosaic Initiative was to transform existing University classrooms into a "mosaic" of classrooms, each different from the other, as a means of harnessing the flexibility and adaptability of design to accommodate a variety of course offerings (Morrone et al., 2017). The initiative also supports faculty development as they learn how to creatively use the space and technologies within these classrooms. As previous participants of the IU Mosaic Initiative Faculty Fellows program, both the first and third authors engaged with other faculty focused on learning more about active-learning strategies and learning spaces in a supportive cohort-based environment. As an instructor in a traditionally low-lecture but highly collaborative field (the first-year writing program), the second author was accustomed to customizing active-learning strategies for use in low-technology general-inventory classrooms.

The two Mosaic classrooms, housing the anthropology and first-year seminar courses, each seated 25 and 40 students, respectively, and contained a range of low and high technologies: large screens for projection; mounted dry-erase glass or whiteboards; smaller, portable whiteboards hung at the sides of desks; and computers loaded with screen-sharing software such as Solstice, Kaltura desktop recording, and learning management systems (e.g., Canvas). Together, faculty and students arranged the flexible furniture each class period to facilitate peer interaction and collaborative activity. The museum studies classroom featured movable chairs and tables, with whiteboards and a projection screen at the front of the room; it is also used as a laboratory space for museum studies graduate students.

Faculty development coupled with the affordances made possible in an active-learning classroom can result in dramatic changes in pedagogy. For example, the first author's experience as a Mosaic Initiative Fellow as well as teaching in a Mosaic classroom inspired her to shift her former approach in teaching of introductory anthropology, a class that she has taught for the last 18 years. Indeed, the space made a large impact on the instructor and her design and delivery of each session. Once she became aware of the configurability of the furniture, she created and implemented student centered discussions of an assigned ethnography (Figure 1); rather than leading the discussions herself, groups of two student facilitators rotated around to four tables of eight students for a timed discussion period.

Space in Mosaic classrooms facilitates a process whereby the boundaries between instructor and student are decreased. When those boundaries are softened, students feel more comfortable approaching the instructor; students are less intimidated by asking a question or making a comment, since both parties have literally been in closer contact, as the instructor must often maneuver and meander among and around the flexible furniture when checking in on small group discussions, for example. The traditional model of the instructor at the front of the room is disrupted; the front of the room becomes wherever the instructor positions her- or himself. For most of the first author's class periods, the front of the room often was the back of the room, closer to the door through which folks entered and exited.

"Faculty often assume that learning takes place only in class" (Mills \& Mehaffy 2016, p. 59). Yet, Mosaic and similar classrooms were not the only "spaces" that were maximized in this TLC. Learning spaces extended beyond the classroom; for example, the museum studies class occasionally 
used the adjacent hallway and lobby for group work. Also, during museum visits (Figure 2), students encountered a set of resources and spaces, some of which are readily available to most visitors: museum websites, parking lots, galleries, and guided tours. However, because of their membership in the TLC, students had access to additional resources not available to most museum visitors, such as a behind-the-scenes tour to collections storage in one museum and specially briefed docents during another tour. During most visits, TLC students were afforded the opportunity to interact with museum professionals, and staff at museums consulted with at least three students about their final projects. ${ }^{4}$ One student's final project was directly inspired by a museum visit. The visits also provided the opportunity for students to interact with their peers and professors in less formal learning environments, and to apply their learning in new spaces.

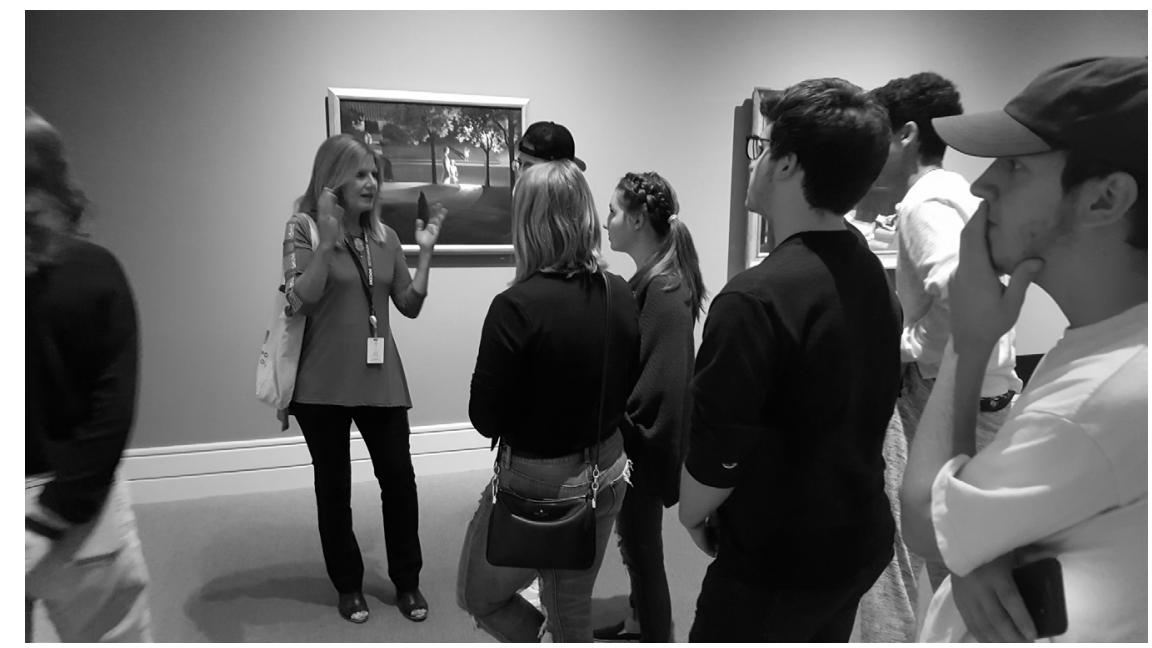

Figure 2. IUPUI students at the local museum of art, September, 2018. Photo courtesy F. Kissel.

As noted by Mills and Mehaffy (2016), "Students learn all the time, individually and collectively, within and beyond classrooms and institutions" (p. 59). In this and in all of our campus TLCs, students are assigned individual meetings or group learning tasks in many spaces on campus to increase their sense of belonging as well as to hone their ability to problem-solve. One example is that groups conducted a digital scavenger hunt to familiarize themselves with key campus resources. To develop civic-mindedness, students engaged in a philanthropic fashion show benefiting Paw's Closet, a free clothing store on campus. Hands-on research sessions were scheduled in the library, where students learned to conduct research using digital formats of familiar print media, while also learning about scholarly sources, new to most. Moveable furniture gave way in one classroom to accommodate a large circle of floor space for group community-building and resilience activities. Digital meeting spaces were not neglected; students created videos about potential internships and posted them to the learning management system. Students also used the digital space of the learning management system to respond to prompts from the instructor to reflect on their visits to museums and make connections between what they were learning in class and their field trips. Inherent in the purposeful consideration and use of space is instructors' explicit encouragement of first-year students to leave the classroom,

\footnotetext{
${ }^{4}$ An educator from the Indianapolis Zoo generously met with the students via Skype to prepare them for their visit. The educator explained the relationship between the zoo's mission and its strategy for interpreting the animals and their habitats. The discussion also focused on the responsibilities that an accredited zoo assumes for the welfare of its animals.
} 
individually or in groups, and thus share ownership of the knowledge created, at times in interstitial learning spaces.

\section{Technologies}

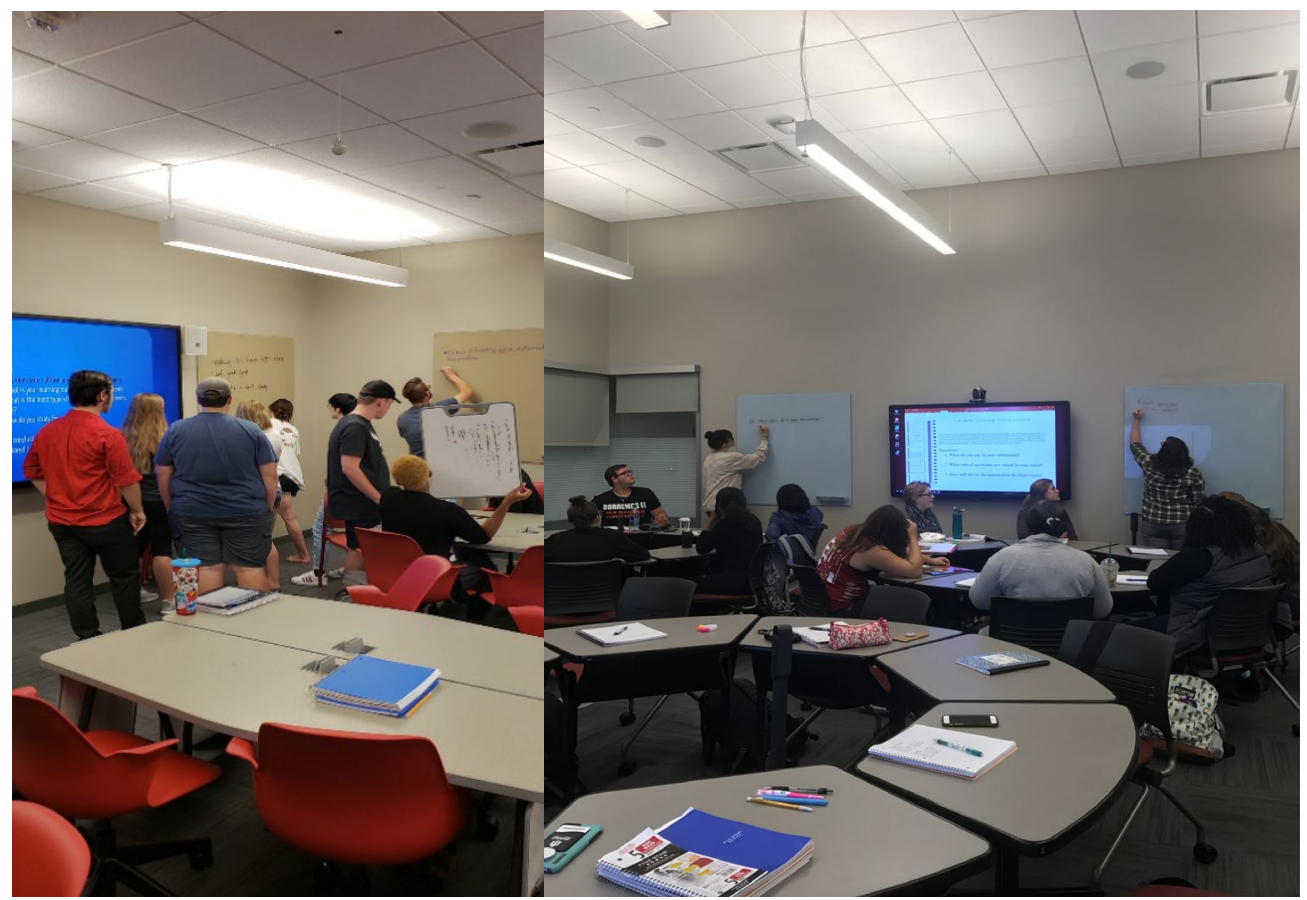

Figure 3. A Mosaic classroom at IUPUI, August, 2018. Photo courtesy G. Gibau. Figure 4. A Mosaic classroom at IUPUI, September, 2017. Photo courtesy G. Gibau.

Technology is not simply that which is plugged into an electrical wall socket or vertical power strip. The term is more capacious and can be conceptualized more broadly. From an anthropological perspective, technology is a tool used by humans to both enhance the lived experience and to express themselves while adapting to their environment (Heidegger, 1977, as cited in Falck, 2014). In the learning environment, students have access to and deploy a myriad of technologies, of the low, middle, and high varieties, as tools with which to acquire knowledge and intellectual growth.

The technologies deployed in this TLC ranged from glass and whiteboards and projection screens (Figure 3) strategically placed around the classroom, to embedded advanced classroom technologies as well as student technologies brought into the classroom in the form of cell phones and laptops. In the anthropology course, for example, students were directed through an exercise in which student and classroom technologies interfaced: For a gender scavenger hunt, students were asked to take pictures outside of class time of collected items and then use Solstice to display and discuss their findings, sharing images from their phones or laptops with the larger projecting screens in the room. For this exercise, several students could upload several photos at a time into the Solstice platform and then wait their turn to present.

However, alongside the advanced technologies, portable and larger mounted glass/whiteboards were used as a technology through which students processed and reflected upon their small group discussions. In the anthropology course, students were asked first to discuss an issue, usually through problem-based inquiry, and then to relay a summary of their discussions, in bulleted list format, on the boards. In this way, whiteboards function as a tool for peer review of thought 
processes in problem solving, while stimulating self-reflection (Birdwell, 2018). Students would then share what they wrote with the rest of their peers during a larger group discussion. The use of lowtechnology tools allows instructors to respond to diverse needs of learners; they appeal to students who appreciate verbal or written engagement, while simultaneously engaging both extroverted and introverted students.

The use of whiteboards in particular (mounted or portable) fosters student collaboration in small groups (MacIsaac, n.d.), serving as a tactile medium with which to ground discussion and problem solving. Whiteboards foster greater dialogue and peer-to-peer learning among students who engage in a more active treatment of the course content as a result. The use of whiteboards as a technology works well in TLCs because it fortifies collaborative learning as an expectation occurring within a community. This type of learning is decidedly more active: It decreases lecture time and empowers students to direct the flow of learning through inquiry and articulation, thus fostering deeper learning, as students learn by doing with others (e.g., "whiteboarding") and not by passively listening to the instructor as a singular source of information.

The instructor's role in this process is to circle the classroom, monitoring the thought process, affirming student progress toward solutions, lifting up student examples within and between groups, and moving on to the next segment of the class when small group discussions veer off topic (MacIsaac, n.d.). In this way, student-teacher interaction and dialogue are also enhanced. Continuing this practice over time effectively blurs the boundary between student and instructor, which can foster significant learning gains and increase students' sense of belonging, particularly in the first year. This has been explained elsewhere (Rands \& Gansemer-Topf, 2017, p. 29) as "erasing the line" or the invisible boundary between instructor and students, typical of traditional classrooms.

\section{Integrative Assignment}

Another important feature of TLCs is the construction of a culminating "integrative assignment" that spans all of the linked courses. For this TLC, the integrative assignment was a "pop-up" museum exhibit. Pop-up exhibitions, sometimes referred to as pop-up museums, are "ephemeral, experimental" projects (Grant, 2015). Pop-up exhibitions, which take place in sites outside of traditional museums and last for a brief time, ranging from hours to weeks, are a manifestation of museums' attempts to connect people with collections through experiments such as mobile museums (Bernard, 2015; Burns, 2013) and museums without walls. Like more traditional museums, they bring together "objects, visitors, and expertise" (Lubar, 2017), but they are often sited outside of museum buildings, in places such as parks, hospitals, or shopping malls. The experimental nature of these projects has made them popular among educators (Latham, 2017), and for the purpose of this TLC, a pop-up provided the opportunity for students to act as curators of their own exhibits, as they identified their topic, developed a theme, and interpreted objects on museum labels using anthropological concepts (see Appendix A for the project description). Through this integrative assignment, students applied their research and writing skills in a setting beyond the classroom and for an audience beyond their instructors. ${ }^{5}$

We chose to focus on several aspects of the curatorial process: identifying a theme that illustrated a human story; interpreting objects using an anthropological lens; and choosing objects that illustrated those themes. We decided not to focus on "real" three-dimensional objects (although this was in the initial discussion), in part because we had concerns that the students might feel limited by

\footnotetext{
${ }^{5}$ Audience members included the advisor for the TLC, a school administrator, and a student who had been in the previous year's TLC. And of course, the audience included other students in the TLC, a point that was reinforced by the students' peer feedback forms (see Appendix B).
} 
objects to which they had access. Most students chose to represent their objects using photographs. Some students did use objects, particularly digital objects (e.g., YouTube video of protesters chanting lyrics to a Kendrick Lamar song). These parameters meant that students may have chosen themes that would not have been easily supported by objects in their possession (e.g., violence against women, LGBTQ artists, climate change, the history of Santa Claus). A focus on objects accessible to the students, however, may have resulted in projects in which students had a different type of personal connection.

To complete this assignment, students were required to research a topic of their choosing, identify three objects associated with that topic, and construct an exhibit, inclusive of interpretive labels, that would relay a human story through images of the objects, presented formally by the students through PowerPoint on a 50 -inch screen in a meeting room in the campus library. Each student's pop-up exhibit used print-outs from their PowerPoint presentation mounted on walls and columns in a typical conference room, transforming an otherwise rectangular, white-walled room into an exhibition space (Figure 5). This exercise is instructive, as it illustrates how the physical transformation of general use classrooms into active learning spaces does not have to be a costprohibitive endeavor dependent upon large-scale institutional funding. 

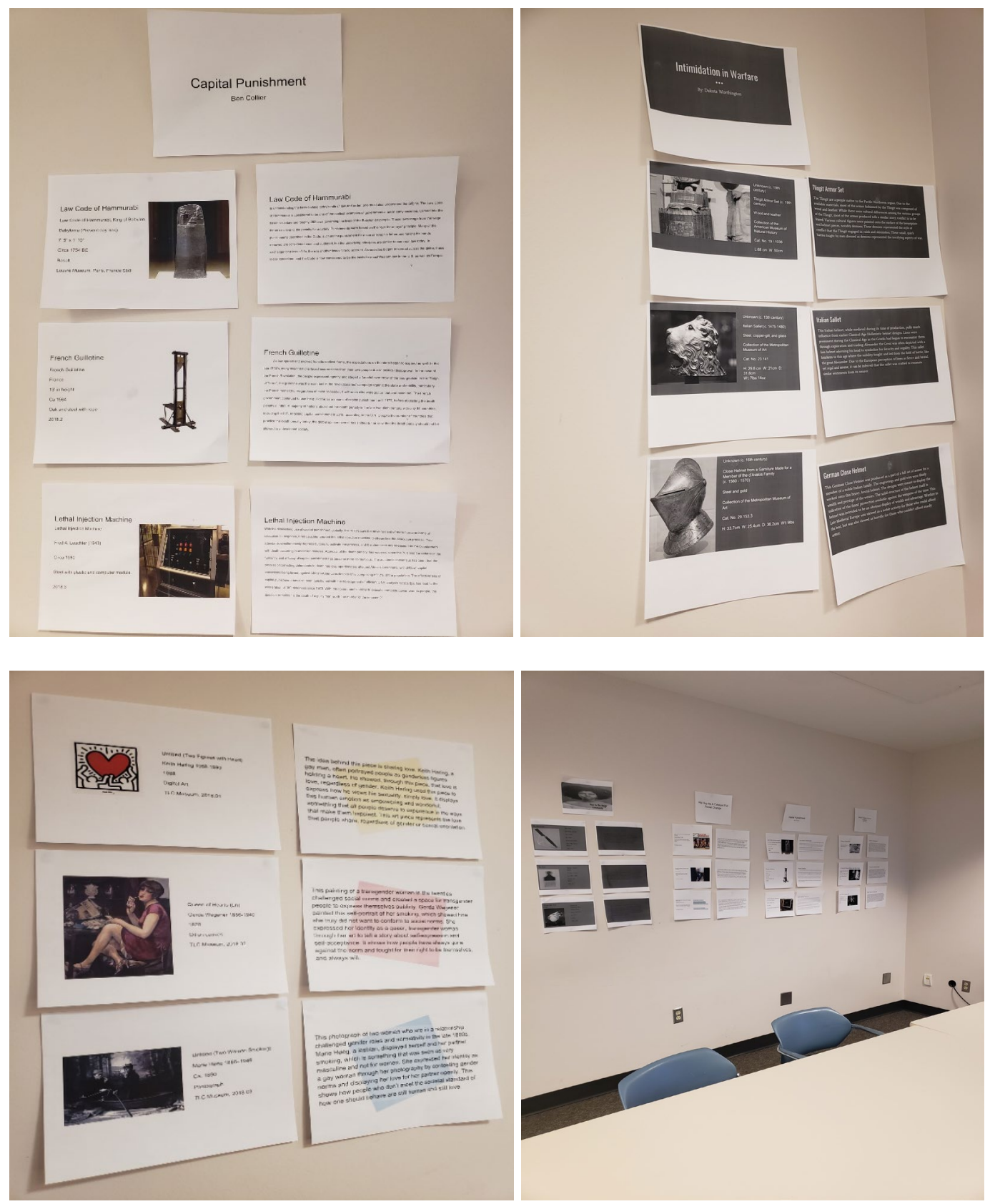

Figure 5. Pop-up museum exhibits, December, 2018. Photos courtesy G. Gibau.

Integrative learning must be scaffolded, hence the benefits of a common assignment with multiple components spread across linked courses. As a means of scaffolding the components of this assignment for the students, each of the instructors created assignments that together supported the students' development and execution of the exhibit. In the first-year seminar course, students conducted research and submitted annotated bibliographies including the images that served as content for the exhibit and the text resources that informed their labels. In the anthropology course, students were required to submit a process paper that served as a means through which students could reflect upon their project and the research conducted to complete it. Finally, in addition to the actual exhibit and presentation, the first assignment in the museum studies course laid the groundwork for the final project by tasking students with reflecting on an object that had personal significance and 
delivering a short in-class presentation about that object. Check-in points were built into the syllabus of each class. Additionally, the course included several workshop days during which students worked on their exhibition labels and object research in class.

The space of the classroom and the learning experience facilitated therein is traditionally thought of as controlled principally by the instructor. However, through the presentations of pop-up exhibits in this TLC, the control of the classroom is effectively surrendered to the students. They are charged with presenting information in a captivating way, educating their peers on their topic effectively, and fielding questions thereafter. The space is opened up for students to assume accountability for their own learning and that of their peers. In this way, the project is aligned with what has been referred to as "heutagogy," or the creation of a space by students in which they "assume greater responsibility and control over the content and skills chosen for mastery" (Garner, 2018, p. 1). This space is decidedly learner centered and self-directed; for this project, students are required to "communicate their learning" by creating a pop-up museum exhibit and presenting the research behind its construction (Garner, 2018, p. 2). They function as curators, exhibit designers, researchers, and educators, all roles they learned from field trips and subsequent classwork.

\section{Results and Future Implications}

The case of The Human Story TLC illustrates how instructors can work collaboratively and intentionally to ensure student learning through the integration of spaces and technologies. The outcomes related to this case speak not only to the value of interdisciplinary instruction but to the adaptability of this approach to similar courses. While many institutions are constrained by the expense of transforming a traditional classroom into one similar to our Mosaic classrooms, this case highlights how active-learning strategies can be deployed in any classroom, inclusive or devoid of advanced technologies. In our experience, the technologies themselves did not facilitate the active learning, but rather it was the ways in which instructors leveraged spaces and technologies that solidified opportunities for student engagement. Starting with the space is critical; instructors must then envision how the desired learning outcomes can be elicited in a given space, enact pedagogies to facilitate that learning, employ technological tools effectively, and reflect upon their praxis accordingly.

The intent of our TLC was for students to integrate skills and knowledge from all three courses, to create products that combine both visual and textual elements, and to present their work effectively, all as a means of showcasing their learning. In end-of-course evaluations, students cited the activities they completed in small groups and other peer-to-peer activities to be the most valuable of their experiences. ${ }^{6}$ As a result of their experiences in this TLC, students engaged in conversations with their instructors about their future career aspirations as shaped from the course content and activities. The students in our courses also exhibited a sense of belonging and acculturation to each other and to academic life. Finally, through interaction with local museums and their staff, students were taught the value of civic engagement and responsibility. The outcomes outlined here contribute to existing literature pertaining to evidence-based practices.

As instructors, we believe strongly in the power of intentional course design and team-oriented pedagogy. While such teaching actions are often situated in the realm of the "experimental," we contend that today's students are best served by such strategies that lead to deeper student learning and engagement. Active-learning approaches powered by effective use of both low and high technologies as well as flexible learning spaces are student centered and thus essential for meeting the

\footnotetext{
${ }^{6}$ Students were not able to provide feedback on the pop-up exhibit through course evaluations because the exhibit occurred after the online evaluation period had closed.
} 
demands of both students and employers as we attempt to prepare an increasingly diverse student population to live, work, and interact within dynamic and complex communities.

\section{Acknowledgments}

The authors extend their gratitude for the invitation to publish in this special issue to its guest editor, Dr. Anastasia Morrone. Additional thanks are extended to Tracey Birdwell and Kelly Scholl of the IU Mosaic Initiative. The authors further acknowledge the direction and support for The Human Story TLC offered by Amy Powell and the IUPUI Division of Undergraduate Education. Special thanks go to Dr. Elee Wood, who helped develop and deliver the first iteration of the TLC with the first two authors in 2017. Finally, the authors acknowledge the area museums and their staff that opened their doors to our students, especially Kisha Tandy, associate curator of social history at the Indiana State Museum; Laurie Christie, program educator, Indianapolis Zoo, and Allie Combs, higher education liaison at the Indianapolis Museum of Art, and the museum's team of docents.

\section{Appendices}

\section{Appendix A. "The Human Story" Pop-Up Museum Project}

Pop-up museums are temporary exhibits that curators create in places that are unexpected. Some pop-up museums last only one day. In this TLC, you will be working in all your classes to a create a pop-up museum about "The Human Story." As curators, you will be selecting the three objects that you will interpret using anthropological concepts that will help visitors learn more about "The Human Story." Curators not only select objects that they will interpret; they also research the object and write exhibition labels so that visitors can see how the theme supports the object.

In each class in this learning community, you will be completing assignments and exercises that will help you finish the project. These assignments and projects bring together the key concepts in our learning community.

Key concepts in this learning community

\begin{tabular}{|l|l|l|}
\hline Audience & Collections & Cultural relativism \\
\hline Culture & Curate/Curation & Ethnocentrism \\
\hline Exhibit/Exhibition & Identity & Museum \\
\hline Object & Race as a cultural construct & Reflect \\
\hline Story/Storytelling/History & Self-identity & \\
\hline
\end{tabular}

Our pop-up exhibition will be on Monday, December 10, in room 1126 of the University Library and will be open from 10:30-3:00 p.m. Some pop-up exhibits bring in artifacts, but ours will be low tech. You will make PowerPoint slides of the three objects you will be interpreting, and post 
them on the walls. Visitors will be able to walk around and read your labels, just like at an exhibition. The sky's the limit when it comes to the objects you can choose to interpret.

How the classes connect

- Cultural Anthropology: This is where it all begins and ends. You will choose to interpret an object using the themes that you study in this class. The Process Paper assignment will be based on your experience creating your exhibition.

- Understanding Museums: You've already started thinking about interpreting objects with our first visit to a museum and your personal museum project presentation and essay. As we visit museums, pay attention to the exhibition labels, which we will be working on in this class. The presentation will also be part of this class.

- First Year Success Seminar: You will be selecting the topic you want to interpret and researching your object. The annotated bibliography will include your research into how your objects tell a human story.

Appendix B. Pop-up Museum Presentation Evaluation Form

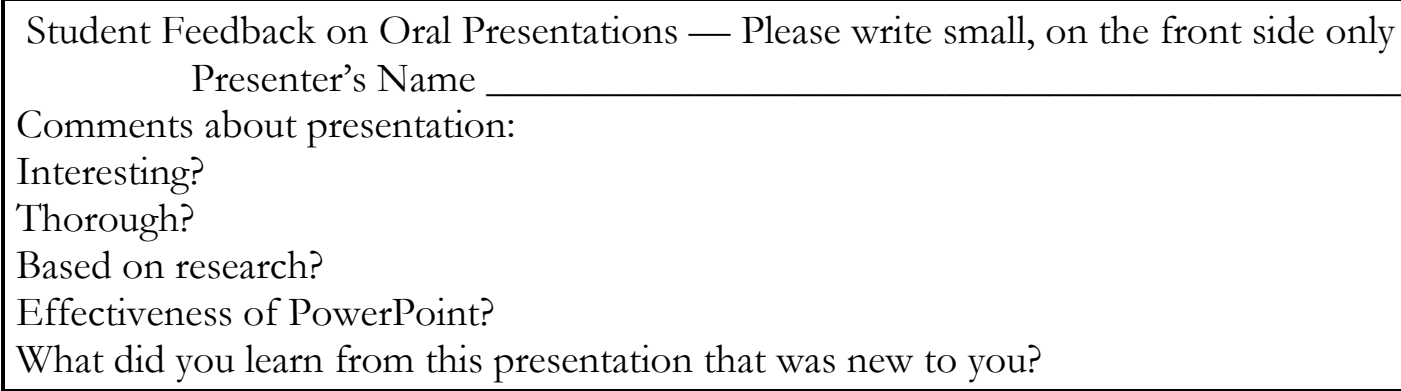

\section{References}

American Alliance of Museums. (2019). About AAM. Retrieved from https://www.aamus.org/programs/about-aam/\#

Araujo, N., Carlin, D., Clarke, B., Morieson, L., Lukas, K., \& Wilson, R. (2014). Belonging in the first year: A creative discipline cohort case study. The International Journal of the First Year in Higher Education, 5(2), 21-31. https://doi.org/10.5204/intjfyhe.v5i2.240

Bandy, J. (2018). Created opportunities for students to apply course content outside of the classroom. Retrieved from https://www.ideaedu.org/Resources-Events/Teaching-LearningResources/Created-opportunities-for-students-to-apply-course-content-outside-theclassroom\#132498-why-this-matters

Beichner, R. J., Saul, J., Abbott, D., Morse, J., Deardorff, D., Allain, R., Bonham, S. W., Dancy, M. H., \& Risley, J. (2007). Student-Centered Activities for Large Enrollment Undergraduate Programs (SCALE-UP) project. In E. Redish \& P. Cooney (Eds.), Research-based reform of university physics (pp. 1-42). College Park, MD: American Association of Physics Teachers. http://www.per-central.org/document/ServeFile.cfm?ID $=4517$

Bennett, S. (2007). First questions for designing higher education learning spaces. Journal of Academic Librarianship, 33(1), 14-26. https://doi.org/10.1016/j.acalib.2006.08.015

Bernard, E. (2015). A shared mobility: Community curatorial process and the Philadelphia Public History Truck. Exbibitionist: Journal of National Association for Museum Exbibition, 2015(Spring), 64-68. Retrieved from https://www.name-aam.org/exhibition spring2015 
Birdwell, T. (2018, August 8). Encouraging group discussion with Verb boards [Blog post]. Retrieved from https://blogs.iu.edu/[university branded ALC]iu/2018/08/08/encouraginggroup-discussion-with-verb-boards/

Brooks, D. C. (2011). Space matters: The impact of formal learning environments on student learning. British Journal of Educational Technology, 42(5), 719-726. https://doi:10.1111/j.1467$\underline{8535.2010 .01098 . x}$

Burns, A. A. (2013). From storefront to monument: Tracing the public bistory of the Black Museum Movement. Amherst, MA: University of Massachusetts Press.

Ewell, P., \& Wellman, J. (2007). Enhancing student success in education: Summary report of the NPEC initiative and national symposium on postsecondary student success. Retrieved from https://nces.ed.gov/npec/pdf/Ewell Report.pdf

Eyler, J. (2009). The power of experiential. Liberal Education, 95(4), 24-31. Retrieved from https://www.aacu.org/publications-research/periodicals/power-experiential-education

Falck, E. J. (2014). Technology and the memetic self. In S. Thompson (Ed.), Global issues and ethical considerations in buman enhancement technologies (pp. 225-240). Hershey, PA: IGI Global. doi:10.4018/978-1-4666-6010-6.ch013

Felder, R., \& Brent, R. (2009). Active learning: An introduction. ASQ Higher Education Brief, 2(4). Retrieved from http://asq.org/edu/2009/08/best-practices/active-learning-anintroduction. $\% 20$ felder.pdf

Field, K. (2018, June 8). A third of your freshmen disappear. How can you keep them? The Chronicle of Higher Education. Retrieved from https://www.chronicle.com/article/A-Third-of-YourFreshmen $/ 243560$

Garner, B. (2018). A look at heutagogy: New opportunities for self-directed learning. The Toolbox, 17(2), 1-4. Retrieved from https://issuu.com/nrcpubs/docs/toolbox 172 new

Gierdowski, D. C. (2017). The flexible writing classroom as a site for pedagogical reflection. In M. Kim and R. Carpenter (Ed.), Writing studio pedagogy: Space, place, and rhetoric in collaborative environments (pp. 155-174). Ranham, MD: Rowman and Littlefield.

Graetz, K. A. (2006). The psychology of learning environments. In D. G. Oblinger (Ed.), Learning spaces [EDUCAUSE e-book]. Retrieved from https://www.educause.edu/research-andpublications/books/learning-spaces/chapter-6-psychology-learning-environments

Grant, N. (2015). Pop up museums: Participant-created ephemeral exhibitions. Exhibitionist: Journal of National Association for Museum Exhibition, 2015(Spring), 14-18. Retrieved from https://www.name-aam.org/exhibition spring2015

Harvey, E. J., \& Kenyon, M. C. (2013). Classroom seating configurations for 21 st century students and faculty. Journal of Learning Spaces, 2(1). Retrieved from http://libjournal.uncg.edu/ils/article/view/578/454

Herzog, S. (2007). The ecology of learning: The impact of classroom features and utilization on student academic success. New Directions for Institutional Research, 2007(135), 81-106. https://doi.org/10.1002/ir.224

James, P., \& Hudspeth, C. (2017). How do you take learning beyond the classroom in an interdisciplinary first-year seminar? New Directions for Teaching and Learning, 2017(151), 79-95. https://doi.org/10.1002/tl.20250

Kuh, G. D. (2008). High-impact educational practices: What they are, who has access to them, and why they matter. Washington, DC: Association of American Colleges and Universities.

Kuh, G. D. (2016). Student success in college: Creating the conditions that matter [PowerPoint slides]. Retrieved from http://centerforpostsecondarysuccess.org/wpcontent/uploads/2016/10/KuhPPT.pdf 
Lardner, L., \& Malnarich, G. (2008). A new era in learning-community work: Why the pedagogy of intentional integration matters. Change: The Magazine of Higher Education, 40(4), 30-37. https://doi.org/10.3200/CHNG.40.4.30-37

Latham, K. F. (2017). The laboratory of museum studies: Museality in the making. Journal of Education for Library and Information Science, 58(4), 219-235. doi:10.12783/issn.2328$2967 / 58 / 4 / 3$

Lubar, S. (2017). Inside the lost museum: Curating, past and present. Cambridge, MA: Harvard University Press.

MacIsaac, D. (n.d.). Whiteboarding in the classroom. Retrieved from http://physicsed.buffalostate.edu/AZTEC/BP WB/

Mills, S. A., \& Mehaffy, G. L. (2016). Challenging the first year of college: Old models and new imperatives. New Directions for Teaching and Learning, 2016(145), 57-65. https://doi.org/10.1002/tl.20175

Monahan, T. (2005). Globalization, technological change, and public education. Retrieved from https://ebookcentral.proquest.com/lib/iupui-ebooks/detail.action?docID=1111674

Morieson, L., Murray, G., Wilson, R., Clarke, B., \& Lukas, K. (2018). Belonging in space: Informal learning spaces and the student experience. Journal of Learning Spaces, 7(2), 12-22. Retrieved from http://libjournal.uncg.edu/jls/article/view/1667/1277

Morrone, A. S., Flaming, A., Birdwell, T., Russell, J., Roman, T., \& Jesse, M. (2017). Creating active learning classrooms is not enough: Lessons from two case studies. EDUCAUSE Review. Retrieved from https://er.educause.edu/articles/2017/12/creating-active-learningclassrooms-is-not-enough-lessons-from-two-case-studies

Oblinger, D. G. (2006). Space as a change agent. In D. G. Oblinger (Ed.), Learning spaces [EDUCAUSE e-book]. Retrieved from https://www.educause.edu/ir/library/pdf/PUB7102a.pdf

Perrin, J. (2014). Features of engaging and empowering experiential learning programs for college students. Journal of University Teaching \& Learning, 11(2), 1-12. Retrieved from https://ro.uow.edu.au/jutlp/vol11/iss2/2/

Phillipson, A., Riel, A., \& Leger, A. B. (2018). Between knowing and learning: New instructors' experiences in active learning classrooms. The Canadian Journal for the Scholarship of Teaching and Learning, 9(1), 1-20. https://doi.org/10.5206/cjsotl-rcacea.2018.1.4

Rands, M. L., \& Gansemer-Topf, A. M. (2017). The room itself is active: How classroom design impacts student engagement. Journal of Learning Spaces, 6(1), 26-33. Retrieved from http://libjournal.uncg.edu/jls/article/view/1286

Stebleton, M., Jensen, M., \& Peter, G. (2010). Enhancing student engagement in a multidisciplinary, first-year experience course. College Teaching Methods \& Styles Journal, 6(1), 1-6. https://doi.org/10.19030/ctms.v6i1.5514

Valenti, M. (2015). Beyond active learning: Transformation of the learning space. EDUCAUSE Review, 50(40), 31-38. Retrieved from https://er.educause.edu/articles/2015/6/beyondactive-learning-transformation-of-the-learning-space

Zepke, N. (2013). Student engagement: A complex business supporting the first year experience in tertiary education [keynote presentation]. The International Journal of the First Year in Higher Education 4(2), 1-14. https:// doi.org/10.5204/intjfyhe.v4i2.183

Zhao, C., \& Kuh, G. D. (2004). Adding value: Learning communities and student engagement. Research in Higher Education, 45(2), 115-138. http://dx.doi.org.proxy.ulib.uits.iu.edu/10.1023/B:RIHE.0000015692.88534.de 